\title{
Nepal's conservation policy options for commercial medicinal plant harvesting: stakeholder views
}

\author{
Helle Overgaard Larsen, Patrick Delinde Smith and Carsten Smith Olsen
}

\begin{abstract}
There is a huge annual trade in Himalayan medicinal plants but only limited information on their sustainable use and conservation. The aim of this paper is to investigate if sustainable commercial medicinal plant management is promoted by forest policy formation and implementation in Nepal. Data was obtained through 175 semi-structured interviews with persons from five stakeholder groups involved in commercial alpine medicinal plant exploitation and conservation in Nepal: harvesters, traders, District Forest Office staff, staff at departments and ministerial level of the Ministry of Forests and Soil Conservation, and international and local NGOs and donors. The emphasis was on recording respondents' views on the official mechanisms regulating harvest of alpine commercial medicinal
\end{abstract}

plants. It was found that current approaches to nontimber forest policy formation and implementation need to be revised if objectives of conservation and sustainable management are to be achieved. Identified problems include exclusion of harvesters from the policy formation process and widespread agreement among respondents that current collection permits and bans do not strongly affect resource utilization.

Keywords Community forestry, forest policy, Himalaya, Nepal, non-timber forest products, participation.

This paper contains supplementary material that can only be found online at http:/ /journals.cambridge.org

\section{Introduction}

For centuries dried medicinal plant products have passed along market chains from remote Himalayan mountain areas to Indian wholesalers on the Gangetic plain (Edwards, 1996; Olsen, 1998). Because of reports of an increasing demand for Indian plant based medicines (Lambert et al., 1997), harvest levels are believed to be unsustainable (Shrestha \& Joshi, 1996; Rai et al., 2000). Although the possibility that increasing market demand was inducing overexploitation was raised more than 25 years ago (Dobremez, 1976), no macro-scale inventories have been undertaken and the state of the resource is still not known for any of the major traded species.

There is no agreement on the potential of commercial medicinal plant management to contribute

Helle Overgaard Larsen* (Corresponding author) ComForM project, Institute of Forestry, Pokhara, P.O. Box 203, Nepal. E-mail hol@kvl.dk

Patrick Delinde Smith USAID Biodiversity Team, United States International Agency for International Development, Washington, DC, USA.

Carsten Smith Olsen Danish Centre for Forestry, Landscape and Planning, Royal Veterinary and Agricultural University, Copenhagen, Rolighedsvej 23, 1958 Frederiksberg C, Denmark.

*Current address: Danish Centre for Forestry, Landscape and Planning, Royal Veterinary and Agricultural University, Copenhagen, Rolighedsvej 23, 1958 Frederiksberg C, Denmark.

Received 21 May 2004. Revision requested 9 September 2004. Accepted 17 December 2004. simultaneously to conserving biodiversity and improving rural livelihoods. Many studies have documented the importance of non-timber forest products (NTFPs) in poverty alleviation (Balick \& Mendelsohn, 1992; Olsen, 1998) and it has been argued that local people are more likely to sustainably and optimally manage a resource that has a high value to them (Plotkin \& Famolare, 1992; Godoy \& Bawa, 1993). It has also been argued that local people are political actors whose involvement is required in biodiversity conservation and management (Schwartzman et al., 2000). On the other hand, there are few documented examples of sustainable NTFP extraction (Crook \& Clapp, 1998) and it may be that local communities' changing needs and interests will compromise any attempts to establish a sustainable harvest (Terborgh, 2001).

Assessing the degree of sustainability of commercial harvesting of Himalayan medicinal plants is complex and problematic. Throughout the region there seems to be, however, a belief in the potential of commercial medicinal plants to contribute to both improvement of rural livelihoods and biodiversity conservation, and a number of conservation and development projects are being implemented (Balachander, 2002; Aumeeruddy-Thomas \& Shengji, 2003). On the basis of a survey of stakeholders involved in medicinal plant harvest, our aim here is to investigate whether the currently applied forest policy formation process and choice of policy tools are successful in contributing to achieving national policy objectives 
Table 1 Statistics for the collection and trade of all Nepalese medicinal plants and alpine medicinal plants.

\begin{tabular}{|c|c|c|}
\hline Information & $\begin{array}{l}\text { All medicinal plants } \\
\text { (from Olsen, 2005) }\end{array}$ & $\begin{array}{l}\text { Alpine medicinal } \\
\text { plants (from Olsen } \\
\text { \& Larsen, 2003) }\end{array}$ \\
\hline $\begin{array}{l}\text { No. of main } \\
\text { products exported }\end{array}$ & 32 & $\begin{array}{l}8+1 \text { fungus and } \\
1 \text { mineral }\end{array}$ \\
\hline $\begin{array}{l}\text { Volume of export } \\
\text { (tons) }\end{array}$ & 14,500 & 1,619 \\
\hline $\begin{array}{l}\text { Export value, } \\
\text { million USD }\end{array}$ & 16.2 & 3.4 \\
\hline $\begin{array}{l}\text { No. of collectors } \\
\text { involved }\end{array}$ & 323,000 & $25,000-35,000$ \\
\hline
\end{tabular}

regarding conservation of medicinal plants and improvement of rural livelihoods. We also discuss proposals to improve current approaches.

Nepal is a major supplier of many commercial Himalayan medicinal plants (Edwards, 1996; Olsen \& Larsen, 2003; Table 1). These plants are considered NTFPs and fall under the jurisdiction of the forest authorities. It is official policy that NTFPs should contribute to improved livelihoods while conserving the resource base (HMG, 1988). Nepal has perhaps the most progressive forestry legislation in the world with respect to local involvement, allowing local communities to take over management responsibility for alpine medicinal plant resources, as in Humla District, for example (Subedi \& Binayee, 2000).

As in other Himalayan countries, the state of medicinal plant resources is unknown (HMG, 2002). Regulation of harvest and trade takes place through the Forest Act (HMG, 1993) and Forest Regulations (HMG, 1995). The Forest Regulations specify that medicinal plants may be collected from National Forests, including alpine meadows, only after acquiring a collection permit from the District Forest Office. The collection permit must specify species, quantities, location and time of harvest. A royalty of around $10 \%$ of harvesters' selling price must be paid for all marketed medicinal plants, and permits are necessary for transport out of the district of origin. Collection of two medicinal plant species (Dactylorhiza hatagirea (D. Don) Soó. and Neopicrorhiza scrophulariiflora (Pennell) D.Y. Hong) and unprocessed exportation of eight others is banned.

\section{Methods}

This study investigates policy decision-making processes at formation and implementation stages by using stakeholder analysis (Grimble \& Chan, 1995). Opinions on official regulation of commercial medicinal plant harvest held by persons involved in medicinal plant harvest, trade, and conservation were collected using an open-ended questionnaire (Appendix). The questionnaire was tested with students (including forest rangers) and faculty members of the Institute of Forestry, Pokhara, Nepal. After rephrasing questions where doubts could arise, the questionnaire was administered face-to-face with 175 respondents. Thirty-five respondents in each of five stakeholder groups involved in medicinal plant harvest, trade and conservation were included. The stakeholder groups were identified on the basis of a previous paper (Larsen et al., 2000): (1) harvesters from eight village development committees (the within-district administrative unit comprising 2,000-15,000 inhabitants) of Gorkha District, (2) local traders and central wholesalers in Banke, Dang, Dhading, Gorkha, Kathmandu and Palpa Districts, (3) District Forest Office staff in Baglung, Dhading, Gorkha, Kaski, Lamjung, Manang and Myagdi Districts, (4) staff in various departments and at the ministerial level of the Ministry of Forests and Soil Conservation, and (5) international and local NGOs and donors with an interest in medicinal plant exploitation and conservation.

The open-ended questionnaire was administered to respondents individually as a semi-structured interview (Kvale, 1996). Selection of respondents was partly based on information from key informants and snowball sampling (Rea \& Parker, 1997), but given the relatively large number of respondents we believe we captured all major opinions. The data was analysed with regards to the different views held by stakeholders on the official regulation of the commercial medicinal plant harvest. Views of course differ among groups and individual stakeholders, and no one group or individual can be claimed to hold the 'correct' view. Rather, the analysis focuses on the consequences of views held by individual groups.

\section{Results}

Results are presented as the percentage of respondents (in total and within groups) holding different opinions regarding policy formation and implementation processes (Table 2).

\section{Views on who can influence policy formation}

When asked whether they felt they could influence the formation of non-timber forest policy, with the question phrased and followed up to include both objective setting, designation of policy tools and implementation, all harvesters answered that they had no influence. As one respondent said 'How should I go and tell people in Kathmandu or the DFO about my thinking here in the village? And why should they listen? They don't have to listen to little people'. 
Table 2 Summary of the views of 175 stakeholders interviewed (see Appendix) about commercial medicinal plant policy formation and implementation processes in Nepal. All figures are in \%.

\begin{tabular}{|c|c|c|c|c|c|c|}
\hline Issue & Harvesters & Traders & $\mathrm{DFO}^{2}$ & MFSC $^{3}$ & NGOs & All respondents \\
\hline \multicolumn{7}{|l|}{ Can you influence policy/rules } \\
\hline \multicolumn{7}{|l|}{ on medicinal plants? } \\
\hline Yes & 0 & 31 & 34 & 49 & 40 & 31 \\
\hline No & 100 & 69 & 66 & 51 & 60 & 69 \\
\hline \multicolumn{7}{|c|}{$\begin{array}{l}\text { What is the purpose of collection } \\
\text { permits? Is the purpose achieved?' }\end{array}$} \\
\hline Royalty & 46 & 75 & 52 & 9 & 46 & 45 \\
\hline Yes & 46 & 9 & 49 & 9 & 6 & 23 \\
\hline No & & 63 & 3 & & 40 & 21 \\
\hline Don't know & & 3 & & & & 1 \\
\hline Monitoring & & 26 & 23 & 77 & 46 & 34 \\
\hline Yes & & 9 & 3 & 11 & 3 & 5 \\
\hline No & & 14 & 20 & 60 & 43 & 27 \\
\hline Don't know & & 3 & & 6 & & 2 \\
\hline $\begin{array}{l}\text { Permit always required, } \\
\text { regardless of follow-up }\end{array}$ & & & 20 & 14 & 3 & 8 \\
\hline Yes & & & 20 & 14 & & 7 \\
\hline No & & & & & 3 & 1 \\
\hline Don't know & & & & & & \\
\hline Don't know & 54 & & 6 & & 6 & 13 \\
\hline \multicolumn{7}{|l|}{$\begin{array}{l}\text { Do bans protect alpine } \\
\text { medicinal plants? }\end{array}$} \\
\hline Yes & 6 & 9 & 20 & 17 & 17 & 14 \\
\hline No & 71 & 86 & 69 & 71 & 69 & 73 \\
\hline Don't know & 23 & 6 & 11 & 11 & 14 & 13 \\
\hline \multicolumn{7}{|l|}{ Comments on bans: $:^{1,5}$} \\
\hline Immoral due to poverty & & & 4 & 12 & 46 & 12 \\
\hline $\begin{array}{l}\text { Bans would be ok } \\
\text { if they worked }\end{array}$ & & 10 & 75 & 60 & 29 & 34 \\
\hline $\begin{array}{l}\text { Bans are not empirically } \\
\text { /scientifically based }\end{array}$ & 48 & 40 & 13 & 28 & 25 & 31 \\
\hline $\begin{array}{l}\text { Bans are irrelevant, } \\
\text { control is impossible }\end{array}$ & 36 & 50 & & & & 19 \\
\hline $\begin{array}{l}\text { Plants need collection } \\
\text { to regenerate }\end{array}$ & 16 & & 8 & & & 5 \\
\hline \multirow{2}{*}{\multicolumn{7}{|c|}{$\begin{array}{l}\text { Should medicinal plant resources } \\
\text { be handled under Community }\end{array}$}} \\
\hline & & & & & & \\
\hline \multicolumn{7}{|l|}{ Forest legislation? ${ }^{4}$} \\
\hline Yes & 14 & 29 & 49 & 91 & 89 & 54 \\
\hline No & 40 & 14 & 43 & 9 & 11 & 23 \\
\hline Don't know & 46 & 57 & 9 & & & 22 \\
\hline
\end{tabular}

${ }^{1}$ Categories of answers were defined after analysing all responses.

${ }^{2}$ District Forest Office staff

${ }^{3}$ Ministry of Forests and Soil Conservation staff

${ }^{4}$ Data from Larsen \& Smith (2004)

${ }^{5}$ Comments by respondents who said that bans do not protect alpine medicinal plants; percentages are calculated on the basis of the number of negative responses.

Central wholesalers in the Terai, the plain at the foot of the Himalayas bordering India, replied that while they cannot influence actual policy formation, they can influence the interpretation of specific rules through their organization. The district forest officers and rangers said they can communicate their ideas and observations to the central authorities where they will be duly taken into account. Ministry of Forests and Soil Conservation staff felt they could influence the formation of rules through giving advice to legislators, mostly regarding details on medicinal plant resources and trade. But some Ministry respondents were frustrated because they felt their advice was rarely heeded.

Respondents from local and international NGOs felt they can influence policy making through seminars, workshops and participation in joint technical committees. Influence was also exercised by raising issues in public debate and presenting success stories from 
projects. Some of the respondents argued that NGO influence on non-timber forest policy was limited because in seminars and workshops the same conclusions have been made for years, and little has changed. An exception was the lifting in February 2001 of the ban on collection of Cordyceps sinensis, which made some Ministry and NGO respondents feel their advice had been taken into account. However, $C$. sinensis is not at present being processed in Nepal, and respondents wondered what rationale the change in rules was based upon.

\section{Views on collection permits}

The purpose of the collection permit is believed by respondents to be either royalty collection, resource monitoring, or control over national resources. In practice application for collection permits takes place after harvest. After buying the products from harvesters, traders apply for the permit and pay royalty at the same time. Harvesters who sell their products to traders outside their home district never apply for collection or transport permits. They do not think the District Forest Officer will grant it to them anyway, so they save their time and effort.

Half of the respondents believed the permit system works according to its purpose. Of those who think the purpose is royalty collection, the harvesters, District Forest Office and Ministry respondents said that the system works well, as did the respondents who believed the purpose was the permit in its own right. The latter argue that for any national natural resource harvested by private agents there must be a system of permit issuance, regardless of whether this is followed up by monitoring. Traders and NGO respondents who believed the purpose of permits to be royalty collection said that the system was not working, with large amounts of medicinal plants never registered (because of smuggling or bribery of forestry officials), and therefore much more income from royalty could be collected. Almost all respondents who believed the purpose of permits to be monitoring for sustainable management complained that the data are not used for anything but royalty collection, and that collection permits are not issued on the basis of a resource assessment. Harvesters said that no field monitoring was taking place to confirm whether medicinal plants originate from the area stated in the permit.

\section{Views on the use of collection bans}

There was widespread agreement among respondents that bans do not work to protect medicinal plant resources, but the reasoning behind this opinion varied both between and within stakeholder groups.
Thirty-four percent of those who said bans do not work (mainly District Forest Office and Ministry respondents) were of the opinion that if bans could be enforced they would be a good instrument, whereas 19\% (harvesters and traders) said bans are irrelevant as it is simply not possible for the District Forest Office staff and police to search every person travelling in the countryside. Ministry and NGO respondents viewed harvest to be a result of poverty and therefore thought bans were undesirable and that sustainable harvest should be practised instead. Harvesters reported that many people had stopped collecting banned species out of fear of punishment although some people still collect. The empirical basis of bans was questioned by harvesters and traders, who argued that local plant population data is necessary to formulate any interventions: 'No, I don't understand this thing about bans. Can big people in Kathmandu see how many panchaunle [Dactylorhiza hatagirea] we have in our lekh [alpine pasture area]?' NGO and Ministry respondents also questioned the scientific approach applied in selecting medicinal plants to be banned.

In addition to the above arguments, Ministry and NGO respondents said that bans were objectionable because of the unintended side effects they produce. These include higher prices for illegal products leading to more harvest, and disempowerment of harvesters who may have felt a responsibility towards the medicinal plant resource until bans were imposed. According to harvesters, traders, Ministry and NGO respondents, another spin-off from bans is illegal rent seeking, i.e. forest officers who misuse their controlling powers by demanding bribes from collectors and traders for allowing banned products to pass through controls. Illegal rent seeking was viewed by NGO respondents as a serious offence endangering the sustainable management of the medicinal plant resource as well as a violation of the basic rights of harvesters and traders. Traders and Ministry respondents took a more pragmatic position, saying that illegal rent seeking is inherent in the political system, occuring on all levels of the hierarchy, and that punishing forest officers won't solve the problem. For traders the 'additional royalty' was seen as an investment to make procedures run smoothly, including for those items that are not strictly legal, e.g. export of banned products, and the payment is not considered a major problem.

\section{Views on best management of the medicinal plant resource base}

When asked who should be responsible for any future management of the medicinal plant resource, many harvesters were confused because there is no one in the alpine pastures but them. Suggestions that District Forest Office staff could initiate better regulation of harvest 
were met with wonder: 'The DFO does not come here, he came when the forest was handed over but that was years ago. I don't think he knows jaributi [medicinal plants] and I don't think he would come to the lekh. Even villagers can only go there if they are strong.' Most NGO respondents, some traders and Ministry respondents echoed this opinion and felt local harvesters should have some if not all the management responsibility. However, District Forest Office respondents distrusted harvesters and expressed reservations about hand over of control: 'Community forest hand-over in high altitudes is possible, but it is not a good idea. Those areas should be protected, if they are given to someone up there they will finish the jaributi due to greed.'

Fifty-four percent of the respondents found handing over the medicinal plant resource under the community forestry scheme a good idea. Arguments in favour ranged from believing it is the right of harvesters to manage their own resources (some Ministry and NGO respondents), to the more pragmatic view expressed by many respondents that regardless of official rights the harvesters are currently the actual managers and so the resource may as well be handed over to provide them with incentives for proper management. Twenty-three percent of the respondents did not think handing over is desirable. Some of these believed it is not legally possible. They argue that: (1) the official purpose of community forestry is to fulfil basic needs and is not for profit generation, (2) community forestry must include trees, and/or (3) an area handed over under the community forestry scheme must be subject to active management, and harvest alone cannot meet that demand. Opinions also differed as to whether harvesters are capable of managing the resource sustainably; those respondents in favour of medicinal plants in community forestry generally believed that if not available at present, such skills can be acquired through proper training.

Not only the District Forest Office respondents but also harvesters and traders were wary of applying the community forestry scheme to medicinal plants. Harvesters felt the resource is theirs now, and therefore they did not wish to go to the trouble of being involved with the District Forest Officer. As for the potential benefits from royalties accruing to the community instead of the District Forest Office, the harvesters doubted they could collect royalty from traders. Traders are not familiar with the community forestry legislation. They said that empowering the harvesters sounds like a good idea but doubt whether the District Forest Officer will willingly give away a source of power.

Apart from concerns over harvesters' management capabilities, regardless of being against or in favour of medicinal plants in community forestry, many NGO, District Forest Office and Ministry respondents felt that alpine areas are fundamentally different from areas where community forestry is normally implemented. Their main reservations were: (1) monitoring of alpine resources by local people is not possible as people live far from it, and without monitoring there cannot be management, (2) the resource is presently subject to open access, so who should it be handed over to, and (3) it is too remote for the District Forest Office staff to go there for inventory and supervision, as required for community forests.

\section{Discussion}

\section{The current policy process does not work}

This study shows that the current policy process for nontimber forest products is not working. In particular, many stakeholders felt they have no influence on policy making, with serious consequences for the legitimacy of the policy. The survey also indicates that there is little shared understanding of the objectives of non-timber forest policy in the Nepalese forest administration. Most District Forest Office staff believed the purpose of collection permits to be royalty collection rather than resource monitoring, as envisioned by Ministry of Forests and Soil Conservation staff. This lack of consistency undermines the ability to implement sustainable medicinal plant management because it means that permit allocation has no connection to resource status.

Another administrative obstacle is the persistent problem of rent seeking. It will be difficult to gain harvesters' acceptance of rules as long as forest officers extract illegal rents. Explicitly involving the public in policy making could reduce rent seeking. For example, NGO respondents reported that their presence in a district reduces illegal rent extraction.

If degradation of commercially harvested medicinal plants is occurring, and if no changes in the regulatory approach are made, the decline is likely to continue. If resource degradation is not currently occurring, however, the purpose of rules that limit harvesters' choice of livelihood strategies can be questioned. The present situation is not optimal for conservation or development of medicinal plant resources.

\section{One way forward}

The current central control of medicinal plant conservation and development is not working. A more realistic strategy would be to give harvesters a stake in the future of the resource and access to participate in policy formation and implementation. The non-timber forest policy could explicitly recognize that local harvesters have the right to manage medicinal plant resources. The incorporation of alpine medicinal plants within the community 
forestry programme could be actively addressed by formulating specific operational guidelines. National collection bans could be replaced by local rules formulated on the basis of local plant population data, but this would require data collection by local forest officers in a way that is not presently done. Furthermore, given the limited trust that forest officers have in the local people, hand over under any new regulations could be slow because of resistance by officials who fear the loss of authoritarian forest management practices.

Officially endorsed community medicinal plant management may suffer the same problems experienced in the community forestry programme related to intracommunity distribution of decision making and benefits. Official endorsement may transfer control to local elites (Malla et al., 2003) enabling them to capture valuable resources. In the case of alpine medicinal plants, the large distance from the village to the resource, together with the physically hard nature of harvest, may be what ensures that present harvesters are not excluded from resource exploitation by wealthier groups. Commercial medicinal plant harvesting is not a prestigious activity (Larsen \& Smith, 2004), and the likelihood of exclusion is not great, but problems of benefit sharing may arise when the whole community is entitled to a share as compared to the situation now where the individual harvester sells his product without paying any fees. Avoiding or resolving these issues will require special rules for local benefit sharing and decision making. As was the case for hand over of community forestry, the service of outside facilitators could be of significant assistance in the creation of equitable community medicinal plant management.

\section{Conclusions}

If the Nepalese forest policy objective of sustainable management of commercial medicinal plant resources is to be achieved, the current approaches to policy formation and implementation need to be changed. The present path leads neither to sustainable livelihoods for harvesters, nor to sustainable medicinal resource management. Most stakeholders involved in commercial harvest and conservation of alpine medicinal plants in Nepal considered the current official regulation to be inefficient in terms of resource monitoring, management and protection of threatened species. Given the unfeasibility and undesirability of militant control, it seems that increased participation of local harvesters in management is indispensable for a sustainable solution.

More than half of the interviewed stakeholders found the concept of community management useful for medicinal plants. A potential benefit, in addition to empowerment and increased transparency, of formal local management is that the sense of ownership may generate an increased concern among harvesters for conservation. As a result they may search for the sustainable balance between conservation and use of medicinal plants and in so doing achieve the medicinal plant management outcomes that have eluded the collection ban and permit policies. There is already some experiences of this, e.g. researchers working together with local people in Dolpa and Humla Districts to examine the effect of collection on medicinal plant populations (Subedi \& Binayee, 2000; Lama et al., 2001), and the challenge for policy makers and administrative staff will be to start relying on the capabilities of rural harvesters.

Forestry that takes into account the aspirations and needs of local people has been pursued in Nepal for more than 25 years but this study has shown that significant changes in approach are still required to promote conservation and sustainable management of non-timber forest resources. It will be an even larger challenge to promote conservation and sustainable use of non-timber forest products in countries with less experience of involving local people in forest policies. In Nepal there are as yet no signs that the present regulations will be changed with respect to further involvement of harvesters in policy making and management. There is, however, increasing official emphasis on promoting non-timber forest products such as medicinal plants, especially for poverty alleviation.

\section{Acknowledgements}

We wish to thank all the respondents for their willingness to contribute to this study, and students at the Institute of Forestry Pokhara for their assistance in testing the questionnaire. Finn Helles and Thorsten Treue (Danish Centre for Forest, Landscape and Planning, Royal Veterinary and Agricultural University, Copenhagen) are thanked for comments on the draft paper. The Council for Development Research of the Danish Ministry of Foreign Affairs and the Royal Veterinary and Agricultural University provided funding.

\section{References}

Aumeeruddy-Thomas, Y. \& Shengji, P. (2003) Applied ethnobotany: case-studies from the Himalayan region. In People and Plants Working Paper 12. WWF, Godalming, UK.

Balachander, G. (2002) Can community-based enterprises promote conservation of biodiversity: issues and challenges. In Medicinal Plants: A Global Heritage, pp. 175-185. International Development Research Centre, Delhi, India.

Balick, M.J. \& Mendelsohn, R. (1992) Assessing the economic value of traditional medicines from tropical rain forests. Conservation Biology, 6, 128-130.

Crook, C. \& Clapp, R. (1998) Is market-oriented forest conservation a contradiction in terms? Environmental Conservation, 25, 131-145. 
Dobremez, J.F. (1976) Exploitation and prospects of medicinal plants in Eastern Nepal. In Mountain Environment and Development, pp. 97-107. Sahayogi Press, Kathmandu, Nepal.

Edwards, D.M. (1996) The trade in non-timber forest products from Nepal. Mountain Research and Development, 16, 383-394.

Godoy, R.A. \& Bawa, K.S. (1993) The economic value and sustainable harvest of plants and animals from the tropical forest: assumptions, hypotheses, and methods. Economic Botany, 47, 215-219.

Grimble, R. \& Chan, M. (1995) Stakeholder analysis for natural resource management in developing countries: some practical guidelines for making management more participatory and effective. Natural Resources Forum, 19, 113-124.

HMG (His Majesty's Government of Nepal) (1988) Forest-based Industries Development Plan, Part II: Medicinal and Aromatic Plants and Other Minor Forest Products. Ministry of Forests and Soil Conservation, Kathmandu, Nepal.

HMG (His Majesty's Government of Nepal) (1993) Forest Act, 2049, Official English Translation. Ministry of Forests and Soil Conservation, Kathmandu, Nepal.

HMG (His Majesty's Government of Nepal) (1995) Forest Regulation, 2051, Official English Translation. Ministry of Forests and Soil Conservation, Kathmandu, Nepal.

HMG (His Majesty's Government of Nepal) (2002) Nepal Biodiversity Strategy. Ministry of Forests and Soil Conservation, Kathmandu, Nepal.

Kvale, S. (1996) An Introduction to Qualitative Research Interviewing. Sage, London, UK.

Lama, Y.C., Ghimire, S.K. \& Aumeeruddy-Thomas, Y. (2001) Medicinal Plants of Dolpo: Amchis' Knowledge and Conservation. People and Plants Initiative, WWF, Kathmandu, Nepal.

Lambert, J., Srivastava, J. \& Vietmeyer, N. (1997) Medicinal Plants: Rescuing a Global Heritage. World Bank Technical Paper 355. The World Bank, Washington, DC, USA.

Larsen, H.O., Olsen, C.S. \& Boon, T.E. (2000) The non-timber forest policy process in Nepal: actors, objectives and power. Forest Policy and Economics, 1, 267-281.

Larsen, H.O. \& Smith, P.D. (2004) Stakeholder perspectives on commercial medicinal plant collection in Nepal: poverty and resource degradation. Mountain Research and Development, 24, 241-248.

Malla, Y.B., Neupane, H.R. \& Branney, P.J. (2003) Why aren't poor people benefiting more from community forestry? Journal of Forest and Livelihood, 3, 78-92.

Olsen, C.S. (1998) The trade in medicinal and aromatic plants from central Nepal to northern India. Economic Botany, 52, 279-292.

Olsen, C.S. (in press) Valuation of commercial central Himalayan medicinal plants. Ambio.

Olsen, C.S. \& Larsen, H.O. (2003) Alpine medicinal plant trade and Himalayan mountain livelihood strategies. Geographical Journal, 169, 243-254.
Plotkin, M. \& Famolare, L. (eds) (1992) Sustainable Harvests and Marketing of Rain Forest Products. Island Press, Washington, DC, USA.

Rai, L.K., Prasad, P. \& Sharma, E. (2000) Conservation threats to some important medicinal plants of the Sikkim Himalaya. Biological Conservation, 93, 27-33.

Rea, L.M. \& Parker, R.A. (1997) Designing and Conducting Survey Research: A Comprehensive Guide. Jossey-Bass Publishers, San Francisco, USA.

Schwartzman, S., Moreira, A. \& Nepstad, D. (2000) Rethinking tropical forest conservation: perils in parks. Conservation Biology, 14, 1370-1374.

Shrestha, T.B. \& Joshi, R.M. (1996) Rare, Endemic, and Endangered Plants of Nepal. WWF, Kathmandu, Nepal.

Subedi, B.P. \& Binayee, S.B. (2000) Linking conservation to business and local communities: an approach to sustainable management of in situ biodiversity in Nepal. In Proceedings of the Third Regional Workshop on Community Based NTFP Management, South-east Asian Countries NTFP Network (SEANN) 8-9 April, 2000 (ed. S.M. Amatya), pp. 34-43. Institute of Forestry, Pokhara, Nepal.

Terborgh, J. (2001) The fate of tropical forests: a matter of stewardship. Conservation Biology, 14, 1358-1361.

\section{Appendix}

The appendix for this article is available online at http:/ / journals.cambridge.org

\section{Biographical sketches}

Helle Larsen's interests include non-timber forest product inventory techniques and research methodologies. She is currently carrying out research on evaluation of the success of community forestry from socio-economic and institutional perspectives, and the valuation of the contribution of forest products to local livelihoods.

Patrick Smith's interests include community-based natural resource management, public participation processes, project planning and evaluation, and criteria and indicators for sustainable forestry.

Carsten Smith Olsen specializes in non-timber forest products and is responsible for research projects in the central Himalaya focusing on trade and investigation of the dynamics of plant-people relationships. He is a member of the IUCN Medicinal Plant Specialist Group and Deputy Coordinator of the IUFRO Working Group on Medicinal Forest Products. 